\title{
GOMOS bright limb ozone data set
}

\author{
S. Tukiainen ${ }^{1}$, E. Kyrölä ${ }^{1}$, J. Tamminen ${ }^{1}$, J. Kujanpää ${ }^{1}$, and L. Blanot ${ }^{2}$ \\ ${ }^{1}$ Finnish Meteorological Institute, Earth Observation Unit, Helsinki, Finland \\ ${ }^{2}$ ACRI-ST, Sophia Antipolis, France \\ Correspondence to: S. Tukiainen (simo.tukiainen@fmi.fi)
}

Received: 5 December 2014 - Published in Atmos. Meas. Tech. Discuss.: 27 January 2015

Revised: 26 June 2015 - Accepted: 10 July 2015 - Published: 5 August 2015

\begin{abstract}
We have created a daytime ozone profile data set from the measurements of the Global Ozone Monitoring by Occultation of Stars (GOMOS) instrument on board the Envisat satellite. This so-called GOMOS bright limb (GBL) data set contains $\sim 358000$ stratospheric daytime ozone profiles measured by GOMOS in 2002-2012. The GBL data set complements the widely used GOMOS nighttime data based on stellar occultation measurements. The GBL data set is based on the GOMOS daytime occultations but instead of the transmitted star light we use limb-scattered solar light. The ozone profiles retrieved from these radiance spectra cover the $18-60 \mathrm{~km}$ altitude range and have approximately $2-3 \mathrm{~km}$ vertical resolution. We show that these profiles are generally in better than $10 \%$ agreement with the NDACC (Network for the Detection of Atmospheric Composition Change) ozonesonde profiles and with the GOMOS nighttime, MLS (Microwave Limb Sounder), and OSIRIS (Optical Spectrograph and InfraRed Imager System) satellite measurements. However, there is a 10-13\% negative bias at $40 \mathrm{~km}$ altitude and a $10-50 \%$ positive bias at $50 \mathrm{~km}$ for solar zenith angles $>75^{\circ}$. These biases are most likely caused by stray light which is difficult to characterize and to remove entirely from the measured spectra. Nevertheless, the GBL data set approximately doubles the amount of useful GOMOS ozone profiles and improves coverage of the summer pole.
\end{abstract}

\section{Introduction}

The GOMOS (Global Ozone Monitoring by Occultation of Stars) instrument on board the Envisat satellite uses the stellar occultation technique for monitoring ozone and other trace gases in the middle atmosphere (Bertaux et al., 2010). Envisat operated from 2002 to 2012 and during that time GOMOS measured altogether around 880000 occultations. While the GOMOS nighttime ozone profiles have generally less than $5 \%$ bias in the stratosphere (Meijer et al., 2004; van Gijsel et al., 2010; Kyrölä et al., 2013), the majority of the daytime occultation profiles are poor due to weak signal to noise ratio (Verronen et al., 2007). For this reason, the GOMOS daytime occultation profiles have not been used in scientific studies.

To improve the GOMOS daytime ozone profiles, Taha et al. (2008) suggested using atmospheric limb radiance of scattered sunlight instead of star spectra for the daytime retrievals. GOMOS measured limb radiances above and below the occulting star using a separate optical path so that the star and the limb contributions can be distinguished from each other (see Bertaux et al., 2010, for a detailed description of the instrument). In principle, the subtraction of the pure limb signal from the central band, containing both the star and the limb contribution, should produce an uncontaminated star spectrum. However, it seems that this removal leads to large and poorly understood uncertainties in the daytime transmission spectra, ruining the operational GOMOS occultation retrieval that works fine for the nighttime data. In their study, Taha et al. (2008) used an optimal-estimationbased method to retrieve ozone from the limb scatter radiances and reported up to $10-15 \%$ agreement with the reference data from Stratospheric Aerosol and Gas Experiment II (SAGE II) between $25-53 \mathrm{~km}$. The authors retrieved separate ozone profiles from both bands (upper/lower) and obtained consistent results.

Following the promising early results of Taha et al. (2008), Tukiainen et al. (2011) developed an alternative method for 
retrieving ozone profiles from the GOMOS limb scattered radiances, or GOMOS bright limb (GBL) measurements as they are referred to from now on. This paper is a continuation of that study. We have processed all GOMOS daytime measurements and in this study we estimate the quality of this novel data set. We also tested the sensitivity of the retrieval method to the selected spectral band and decided to use the lower band radiance to process the GBL data set. Another important decision is the choice of the stray light removal method (GOMOS daytime radiances are badly contaminated by stray light). In this work, we adapted a simple method that estimates the average stray light from the high tangent altitude GOMOS spectra. The structure of this paper is as follows. In Sect. 2 we describe the retrieval method, test its sensitivity, and explain some general aspects of the GOMOS daytime data. In Sect. 3 we describe the correlative data sets used to validate the retrieved GBL ozone profiles, present the comparison method, and show the results of the comparisons. In Sect. 4 we conclude our study and discuss the results.

\section{GOMOS bright limb data}

The GOMOS bright limb data set consists of $\sim 358000$ limb-scattered radiance spectra measured around 10:00 LT between March 2002 and April 2012, from the launch of Envisat to the communication failure that stopped the mission. From these measurements we have retrieved vertical ozone profiles in the $18-60 \mathrm{~km}$ altitude range. The retrieved profiles have approximately $2-3 \mathrm{~km}$ vertical resolution. The data are processed using the ESA IPF (Instrument Processing Facility) Level 1 version 6.01 and the current GBL Level 2 version 1.2. The Level 2 retrieval scheme is based on Tukiainen et al. (2011) with a few modifications. We describe the retrieval method briefly below.

One GOMOS limb "scan" includes typically 120-140 individual radiance measurements at different tangent heights. Since GOMOS records two separate radiance spectra at each tangent height, above and below the central band (which collects the combined star and limb signal), there are actually twice as many spectra. The GBL data set was processed using the lower band radiances but the upper band, or possibly a combination of both bands, could be used as well. The upper and lower band radiances are separated by around $1.5 \mathrm{~km}$ in tangent height. One particular advantage of GOMOS is that the tangent height registration is very accurate: on the order of $30 \mathrm{~m}$ (Bertaux et al., 2010). Stars are point sources and their positions are well known. Because the GOMOS central band always follows the occulting star, the uncertainty in the tangent height, which is often a significant problem in limb scatter satellite observations, is a negligible issue in the GOMOS retrievals (Tamminen et al., 2010).

In the retrieval, the model atmosphere is discretized into homogeneous layers whose center point heights match the tangent heights of the corresponding radiance measurements.
We use an onion peeling retrieval approach to estimate trace gas densities, starting from the topmost layer used in the retrieval (at $\sim 60 \mathrm{~km}$ ) and proceeding layer by layer towards the bottom layer (at $\sim 18 \mathrm{~km}$ ). At each layer, we minimize the cost function

$$
\begin{aligned}
\chi^{2}(z) & =[\boldsymbol{H}(\lambda, z)-\boldsymbol{M}(\lambda, z)] \mathbf{C}^{-1}[\boldsymbol{H}(\lambda, z) \\
& -\boldsymbol{M}(\lambda, z)]^{T},
\end{aligned}
$$

where $\boldsymbol{M}$ is the (stray-light-corrected) radiance measurement at layer $z$ and a function of wavelength $\lambda$. It is normalized with the first measurement below $47 \mathrm{~km}$ of the same scan. The diagonal uncertainty covariance matrix $\mathbf{C}$ includes the standard deviation of the measurement error. Currently, no modeling error is assumed, see details in Tukiainen et al. (2011). The modeled radiance,

$\boldsymbol{H}(\lambda, z)=\boldsymbol{R}(\lambda, z) \frac{\boldsymbol{I}_{\mathrm{ss}}(\lambda, z, \boldsymbol{\rho})}{\boldsymbol{I}_{\mathrm{ref}}(\lambda)}$,

consists of the modeled total to single scattering ratio $\boldsymbol{R}$, calculated in advance as a look-up table, and the single scattering radiance $\boldsymbol{I}_{\mathrm{ss}}$ divided by the modeled reference spectrum $\boldsymbol{I}_{\text {ref. }} \boldsymbol{R}$ depends only weakly on the actual trace gas profiles, allowing us to keep it fixed during the fitting process. With this assumption, we only need to solve the single scattering radiance $\boldsymbol{I}_{\mathrm{ss}}$ which can be effectively calculated using simple numerical integration. The reference spectrum $\boldsymbol{I}_{\text {ref }}$ is estimated using neutral air density from the ECMWF (European Centre for Medium-Range Weather Forecasts) model analysis data (MSIS-90 climatology above $1 \mathrm{hPa}$ ) and climatological trace gas profiles.

The retrieved gas densities, $\rho$, include ozone, aerosols, and neutral air. $\mathrm{NO}_{2}$ is taken from a climatology and kept fixed. The $\mathrm{NO}_{2}$ climatology is based on OSIRIS (Optical Spectrograph and InfraRed Imager System) data (Tukiainen et al., 2008). Aerosol scattering is modeled with the HenyeyGreenstein phase function and aerosol extinction is modeled with the Angström $\lambda^{-1}$ law. Rayleigh scattering is assumed for neutral air. The minimization of $\chi^{2}$ in Eq. (1) is done with the Levenberg-Marquardt method. The error covariance matrix of the retrieved densities is estimated at the minimum assuming Gaussian posteriors:

$\mathbf{C}_{\mathrm{r}}=\left(\mathbf{J}^{\prime} \mathbf{J}\right)^{-1} \frac{\chi^{2}}{(n-p)}$,

where $\mathbf{J}$ is the Jacobian, $n$ is the number of spectral points in the fit, and $p$ is the number of retrieved gases. The error estimates of the retrieved densities are the square roots of the diagonal elements of $\mathbf{C}_{r}$. An example of the ozone profile errors is shown in the left panel of Fig. 1. The relative error (error/density $\times 100(\%)$ ) is $2-15 \%$ depending on the altitude, which is quite a typical range of error values for stratospheric ozone profiles. Scaling the covariance matrix with the reduced $\chi^{2}$ in Eq. (3) leads to more realistic 

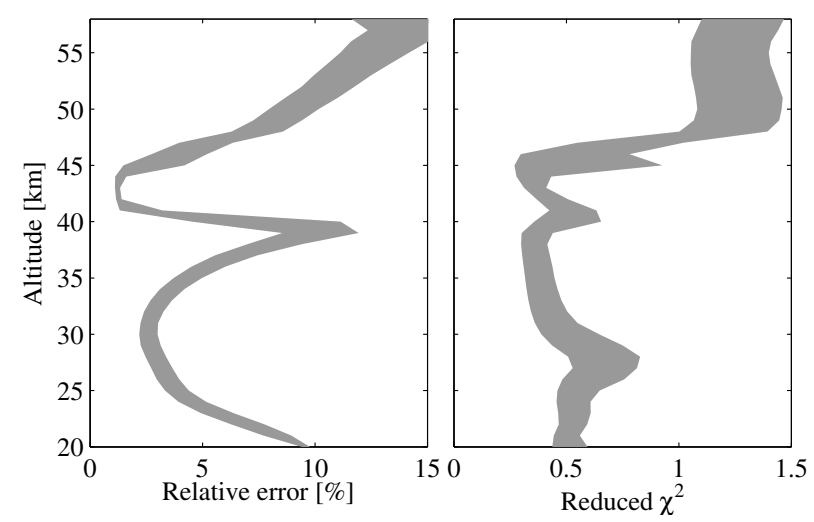

Figure 1. Interquartile range of the relative error (left) and reduced $\chi^{2}$ (right). Data from the tropics, year 2004.

error bars for the profiles. In theory, the reduced $\chi^{2}$ should be unity but the average $\chi^{2}$ of GBL is around 0.5 between 20 and $45 \mathrm{~km}$ and the scaling is needed (Fig. 1, right panel). The GBL $\chi^{2}$ values of less than unity indicate some issue in the measurement error characterization.

GOMOS daytime radiances are significantly contaminated by stray light, especially at visible wavelengths and at high tangent altitudes. For example, below $40 \mathrm{~km}$ at $500 \mathrm{~nm}$ the stray light accounts roughly for a few percents of the signal but already several $10 \%$ at $60 \mathrm{~km}$. We remove the stray light by calculating the average spectrum above $100 \mathrm{~km}$ and by subtracting this constant spectrum from each tangent height. The removal is done independently for each scan. This approach ignores a possible altitude dependence of the stray light but, on the other hand, is a simple and robust method. To avoid using the most corrupted wavelength regions, we use three different sets of retrieval wavelengths depending on the tangent height (Table 1). This reduces bias due to inconsistencies in the GOMOS spectra but also introduces a discontinuity at $40 \mathrm{~km}$ where we start using only visible wavelengths. We reduce the discontinuity by scaling the amount of stray light (at layers below $40 \mathrm{~km}$ ) by an iteratively found constant factor, requiring that the ozone profile remains smooth in the $40 \mathrm{~km}$ transition.

We tested the sensitivity of the GBL ozone to the two important assumptions in the retrieval: the choice of the charge-coupled device (CCD) band of the spectrometer (upper or lower) and the stray light correction method. The test data included 10 orbits (142 scans) from 1 April 2004. The two available CCD bands yield ozone profiles within $1 \%$ (Fig. 2 left panel). The difference is calculated, after linear interpolation in altitude, as (upper-lower) / lower $\times 100(\%)$. This figure visualizes the propagation of the random measurement error in the GOMOS limb retrieval. For the stray light correction, we tested two methods: the constrained extrapolation method introduced in Tukiainen et al. (2011) and the simple average method described above. The difference in the retrieved ozone profiles is below $1 \%$
Table 1. Wavelength ranges used in the retrieval.

\begin{tabular}{ll}
\hline Tangent height range & Wavelength range \\
\hline$>45 \mathrm{~km}$ & $280-300 \mathrm{~nm}, 320-330 \mathrm{~nm}$ \\
$40-45 \mathrm{~km}$ & $300-330 \mathrm{~nm}, 420-425 \mathrm{~nm}$ \\
$<40 \mathrm{~km}$ & $420-680 \mathrm{~nm}$ \\
\hline
\end{tabular}
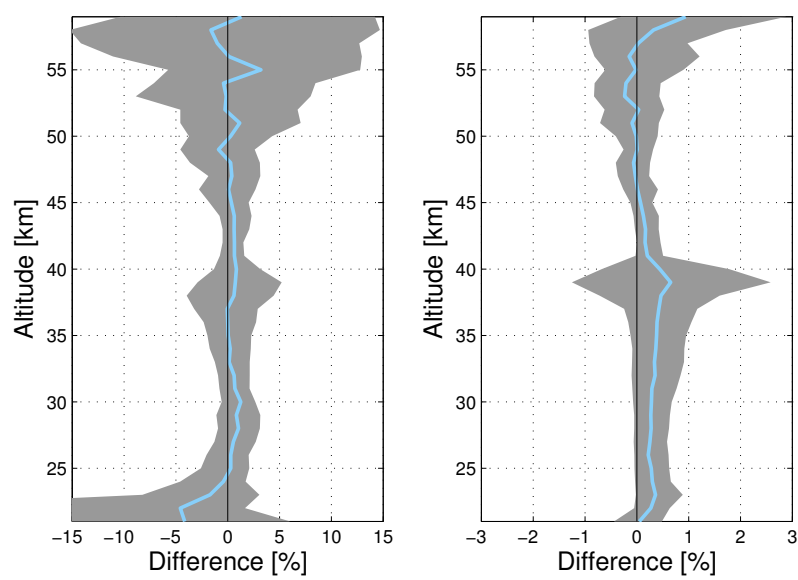

Figure 2. Sensitivity of GBL ozone profile to CCD band (left) and stray light correction method (right). Shown are the mean (solid line) and standard deviation (shaded area) of the relative individual differences of the retrieved profiles in both cases. See text for details.

(Fig. 2 right panel). The difference is defined as (averageconstrained) / constrained $\times 100(\%)$. As both methods produce, at least in this case, almost identical ozone profiles it is probably better to use the average method because of its simplicity.

Each GBL Level 2 file contains geolocation information, ECMWF model values for the temperature and density, a fixed $\mathrm{NO}_{2}$ profile (from the OSIRIS climatology), and residuals of the fit. Densities and error estimates are provided for the three simultaneously retrieved species: ozone, aerosols, and neutral air. In this paper we show only the results related to the ozone profiles. Figure 3 shows the number of GBL profiles and GOMOS nighttime occultation profiles during the whole Envisat mission. The GBL data set roughly doubles the amount of useful GOMOS ozone profiles. Figure 4 shows a typical 1-day coverage of GOMOS day and night measurements, and Fig. 5 shows the number of GBL profiles during 1-year (2004) as a function of latitude. The GBL data complements the night occultations in the tropics and mid latitudes and furthermore expands the global coverage towards the summer pole.

Figure 6 shows an example of the zonally averaged vertical distribution of ozone from the GOMOS nighttime occultations, GOMOS daytime occultations, and GBL. The measurements are from January 2005 and from the latitude $35^{\circ} \mathrm{N}$. The nighttime data are from the star number 2 and 


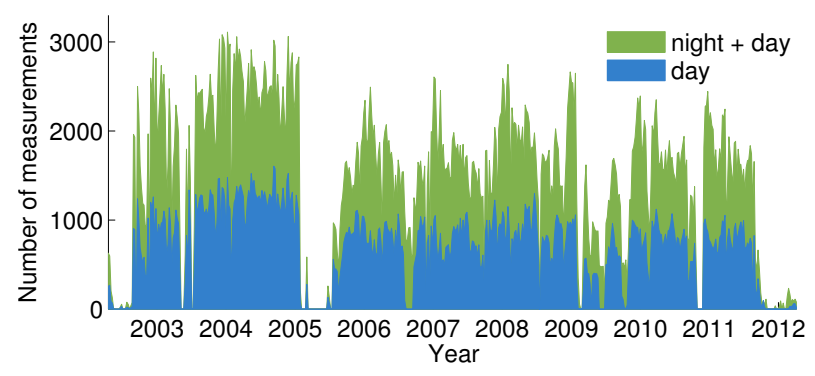

Figure 3. Number of GOMOS nighttime and GBL measurements (weekly).

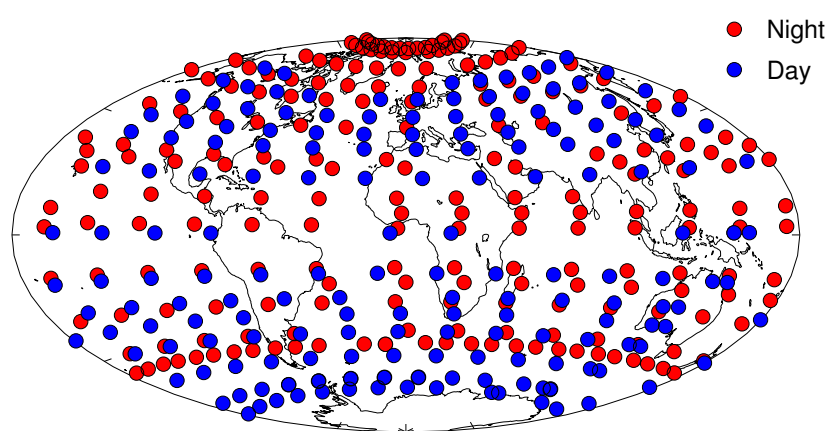

Figure 4. Typical 1-day coverage of GOMOS night occultations (red) and GBL (blue). Data from 15 December 2004.

the daytime data from the star number 175 . As practically always, the shapes of the day occultation profiles are significantly different than the shapes of the GBL and night occultation profiles. The huge fluctuations and large negative values seen in the day occultation profiles are not realistic. At least in the stratosphere, the quality of the day occultation profiles is clearly inferior to the GBL and GOMOS nighttime data.

\section{Correlative data sets}

First, we compared the retrieved GBL ozone profiles against NDACC (Network for the Detection of Atmospheric Composition Change) balloon-borne ozonesonde measurements. The NDACC data can be downloaded from http://www.ndacc.org and the stations that were used in the comparison are listed in Table 2. While ozonesondes typically reach only about $30-35 \mathrm{~km}$ altitude, they measure tropospheric and lower stratospheric ozone with very good vertical resolution. Also, in general, the accuracy and precision of ozonesondes is at least as good as satellite measurements.

To validate the GBL profiles also for altitudes above $35 \mathrm{~km}$, we compared the GBL data against satellite measurements from the GOMOS nighttime occultations, MLS (Microwave Limb Sounder) on EOS (Earth Observing System) Aura (Waters et al., 2006), and OSIRIS on Odin (Llewellyn et al., 2004; McLinden et al., 2012).

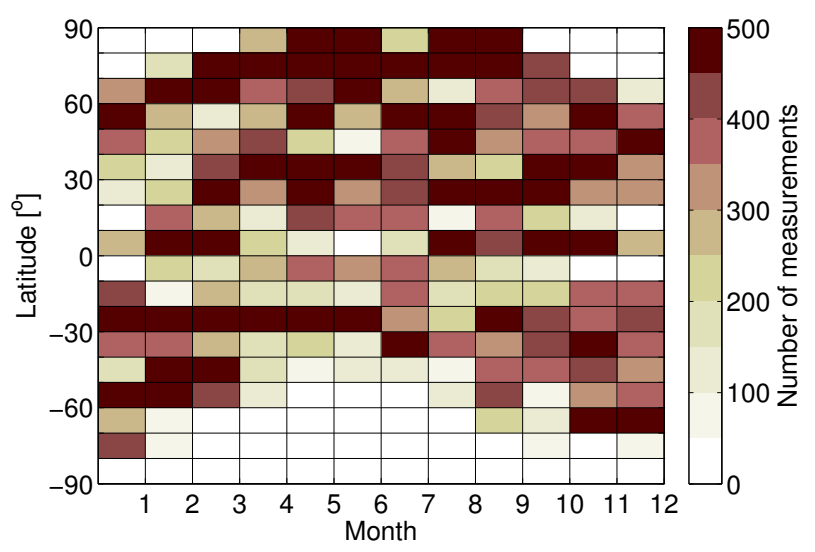

Figure 5. Number of GBL measurements as a function of latitude and time during 2004.

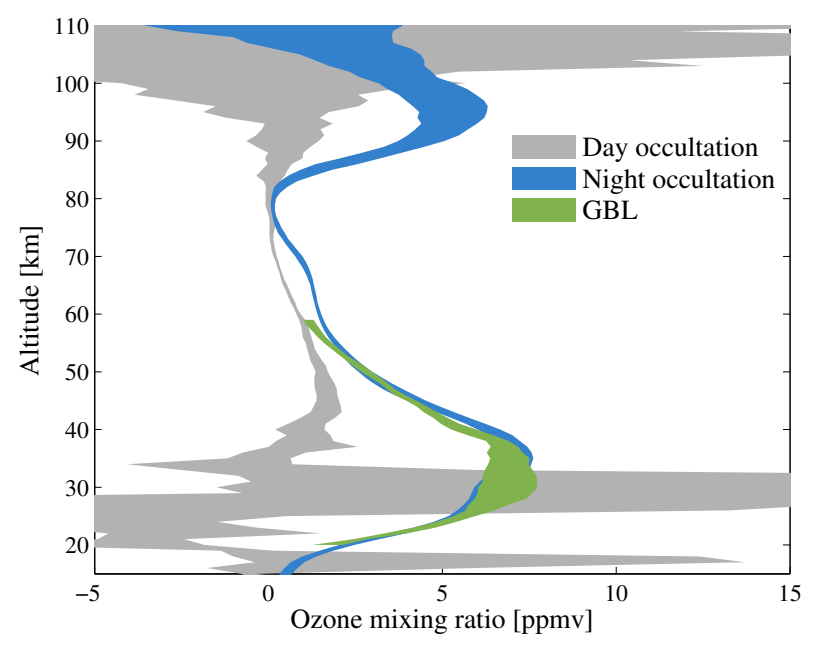

Figure 6. Example of the vertical distribution of ozone from the GOMOS night/day occultations and GBL. Data from January 2005, latitude $35^{\circ} \mathrm{N}$ (zonal medians and interquartile ranges).

For GOMOS night occultations, we used the latest Level 2 version 6 data. Because the occultation retrieval from cool and weak stars is also difficult due to low signal to noise ratio and often results in mediocre nighttime occultation profiles (see the data disclaimer ESA, 2012), we screened out these "bad star" profiles from the comparison.

MLS on board the Aura satellite, launched in July 2004, uses thermal infrared emission to measure the atmosphere between $\sim 0$ and $90 \mathrm{~km}$. MLS measures globally during the day and night, and the accuracy of the MLS ozone profiles is estimated to be better than $5 \%$ in the stratosphere (Froidevaux et al., 2008). In this comparison we used the MLS Level 2 version 3.3 data (Livesey et al., 2011). MLS ozone profiles are mixing ratios as a function of pressure while the GBL profiles are number densities as a function of altitude. Thus, we converted the GBL densities to mixing ratios and pressures using the ECMWF model analysis data (below 
Table 2. NDACC stations that were used for different latitude zones.

\begin{tabular}{lllll}
\hline $60-90^{\circ} \mathrm{N}$ & $30-60^{\circ} \mathrm{N}$ & $30^{\circ} \mathrm{S}-30^{\circ} \mathrm{N}$ & $30-60^{\circ} \mathrm{S}$ & $60-90^{\circ} \mathrm{S}$ \\
\hline Scoresby Sound & Obs. de Haute Provence & Paramaribo & Lauder & Dumont d'Urville \\
Ny Ålesund & Hohenpeißenberg & Izańa & & Neumayer \\
Sodankylä & Legionowo & Natal & & \\
Summit & De Bilt & & & \\
Eureka & Boulder & & & \\
Alert & Wallops & & & \\
Thule & Prague & & & \\
\hline
\end{tabular}

$1 \mathrm{hPa}$ ) and the MSIS-90 climatology (above $1 \mathrm{hPa}$ ), which are included in the GOMOS Level 1 data. It is convenient to use the neutral density data from the Level 1 product, especially as the ECMWF data below $1 \mathrm{hPa}(\sim 50 \mathrm{~km})$ are generally very accurate (errors of less than $1 \%$ ). The MSIS-90 climatology, merged with the ECMWF data, is less accurate though. Nevertheless, we estimate that the accuracy of the GOMOS Level 1 neutral air product between 50 and $60 \mathrm{~km}$ is still better than approximately $5 \%$.

OSIRIS is a UV/visible spectrograph, including a nearinfrared imager, on board the Odin satellite. OSIRIS measures the atmosphere using the limb scatter technique, measuring scattered sunlight and scanning Earth's limb between $\sim 10$ and $100 \mathrm{~km}$. In this work, we have used two different OSIRIS ozone profile products. The University of Saskatchewan's OSIRIS ozone product is retrieved from OSIRIS data using the SaskMART (Saskatchewan multiplicative algebraic reconstruction technique; Degenstein et al., 2009). The product has been the target in several validation studies (e.g., Adams et al., 2012, 2013). In this study we use the version 5.07 of these data. The Finnish Meteorological Institute's (FMI) OSIRIS ozone product is retrieved using the modified onion peeling method (Tukiainen et al., 2008), which is similar to the method used in this work. The present version is 3.2. The two available OSIRIS ozone products agree with each other within a couple of percents.

\subsection{Comparison method}

For each co-located profile pair we calculated the difference as

$\Delta=\frac{X_{\mathrm{GBL}}-X_{\mathrm{ref}}}{X_{\mathrm{ref}}} \times 100(\%)$,

where $X_{\mathrm{GBL}}$ is a GBL profile and $X_{\text {ref }}$ is a reference (NDACC, GOMOS night, MLS or OSIRIS) profile. The coincidence criteria for each instrument are shown in Table 3. To estimate the bias against GOMOS night, MLS and OSIRIS, we calculated the median of the individual relative differences using $10^{\circ}$ latitude zones between $70^{\circ} \mathrm{S}$ and $70^{\circ} \mathrm{N}$. With the NDACC soundings we used only six latitude zones (see Table 2) because the latitude coverage of the NDACC sounding stations is much sparser than of the polar
Table 3. Coincidence criteria for the GBL and correlative measurements.

\begin{tabular}{lrr}
\hline Instrument & $\Delta_{\text {distance }}$ & $\Delta_{\text {time }}$ \\
\hline GOMOS night & $250 \mathrm{~km}$ & $24 \mathrm{~h}$ \\
MLS & $200 \mathrm{~km}$ & $6 \mathrm{~h}$ \\
OSIRIS & $200 \mathrm{~km}$ & $5 \mathrm{~h}$ \\
NDACC sounding & $300 \mathrm{~km}$ & $24 \mathrm{~h}$ \\
\hline
\end{tabular}

orbiting satellites especially in the Southern Hemisphere. We also calculated the bias against GOMOS night occultations as a function of solar zenith angle.

In the median calculation, we used coincidences from all overlapping years. Possible year-to-year differences due to e.g., aging of the instruments were found insignificant (a few percents with no clear pattern) compared to the other sources of bias. In addition, the vertical resolutions of the four different satellite ozone products are similar (2-3 km for GBL, GOMOS night, and OSIRIS, and $\sim 3 \mathrm{~km}$ for MLS). Therefore, these profiles were compared without any vertical smoothing. The vertical resolution of GBL is determined by the field of view of GOMOS and the movement of the satellite during the measurement. These lead to an $\sim 2 \mathrm{~km}$ theoretical resolution in the GBL product, which is further lowered to $\sim 2-3 \mathrm{~km}$ due to the retrieval method, according to our estimate. In the GOMOS occultation retrieval, the resolution is fixed to $2-3 \mathrm{~km}$ (depending on the altitude) using the Tikhonov regularization and target resolution technique (Tamminen et al., 2010). The vertical resolutions of the OSIRIS and MLS ozone products are very close to the GOMOS resolutions and the marginal resolution differences do not seem to cause any notable issues in the comparisons. The NDACC ozonesonde profiles, which have significantly better vertical resolution, were smoothed to the approximately same resolution with the satellite products using a Gaussian filter.

Some of the GBL profiles include outliers especially at the lowermost retrieved altitudes. This measurement is often corrupted because GOMOS has lost the tracking of the star. Before comparisons, we screened the GBL data with the following criteria: 

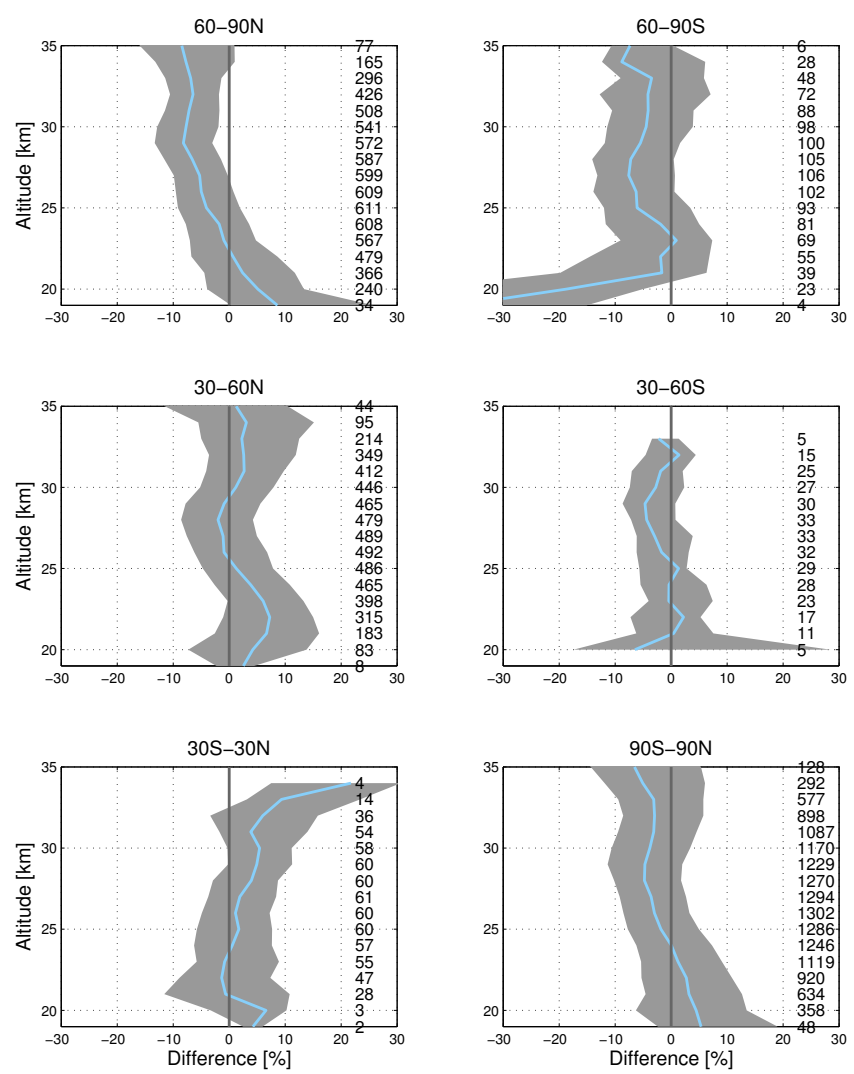

Figure 7. Interquartile ranges (shaded areas) and medians (solid lines) of the individual relative differences of GBL ozone profiles against NDACC ozonesondes for different latitude zones. The numbers are the amount of co-located points at each altitude.

1. always remove the lowest retrieved point;

2. remove points with the reduced $\chi^{2}>10$;

3. remove points below $35 \mathrm{~km}$ where the relative error $\frac{\mathrm{O}_{3} \text { (error) }}{\mathrm{O}_{3} \text { (density) }}>0.1$, where $\mathrm{O}_{3}$ (error) is the error estimate of the retrieved density.

On average, the $\chi^{2}$ screening removes $\sim 0.3$ points per profile and the error screening removes $\sim 1.3$ of the remaining points per profile. This kind of screening significantly improves the agreement in the $20-25 \mathrm{~km}$ range against all studied reference data.

\subsection{Results}

Figure 7 shows the result against NDACC ozonesondes for the six latitude zones. Shown are interquartile ranges and medians of the differences. The numbers represent the numbers of co-located pairs at each altitude. In these comparisons the median difference is always less than $10 \%$ except latitudes $60-90^{\circ} \mathrm{S}$ where the negative bias is more than $-20 \%$ at $19 \mathrm{~km}$.

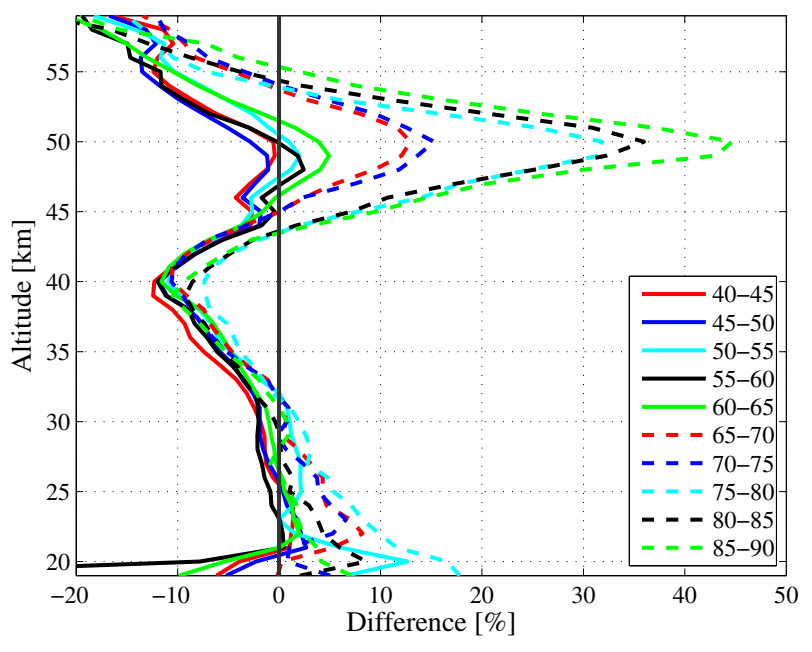

Figure 8. Median relative differences of GBL ozone profiles against GOMOS nighttime occultations for different solar zenith angles.

Figure 8 shows the comparison against GOMOS night occultations for different solar zenith angles. There is a clear positive bias at around $50 \mathrm{~km}$ when the solar zenith angle is $75^{\circ}$ or larger. With smaller solar zenith angles the differences are rather similar. The large solar zenith angle observations account for $16 \%$ of the GBL data and the GOMOS measurement geometry is such that these observations appear mostly at mid and high latitudes. We suspect that the $50 \mathrm{~km}$ bias is linked to stray light and its removal. GOMOS daytime data suffer from serious stray light contamination and in particular the upper altitudes are sensitive to the accuracy of the removal method. We also note that the solar zenith angle seems to be the only parameter that clearly correlates with the $50 \mathrm{~km}$ bias. Some good individual profiles can be found even for high solar zenith angles but there is no clear pattern, or too few profiles to draw conclusions. Because the majority of the GBL measurements with a large solar zenith angle are distinctly biased at $50 \mathrm{~km}$, in the remaining comparisons we only used the GBL data with the solar zenith angle smaller than $75^{\circ}$.

Figure 9 shows the difference in $10^{\circ}$ latitude bins against GOMOS night, MLS, and OSIRIS measurements. The most distinctive feature is the $10-15 \%$ negative bias at around $40 \mathrm{~km}$, which is present in all comparisons. A few percent of this difference can be explained by the diurnal variation of ozone. The GOMOS day measurements are made around 10:00 LT, which is in the minimum of the diurnal curve (Sakazaki et al., 2013). In addition, the MLS afternoon measurements are made around 14:00 LT, which is in the quite recently discovered afternoon maximum of ozone (Sakazaki et al., 2013). We estimate that the diurnal variation explains about $3 \%$ of the $40 \mathrm{~km}$ bias against MLS and around 1-2\% against GOMOS nighttime and OSIRIS. Another notable structure is the negative bias at southern mid/high latitudes, which is several $10 \%$ at $19 \mathrm{~km}$. Large biases exist at 

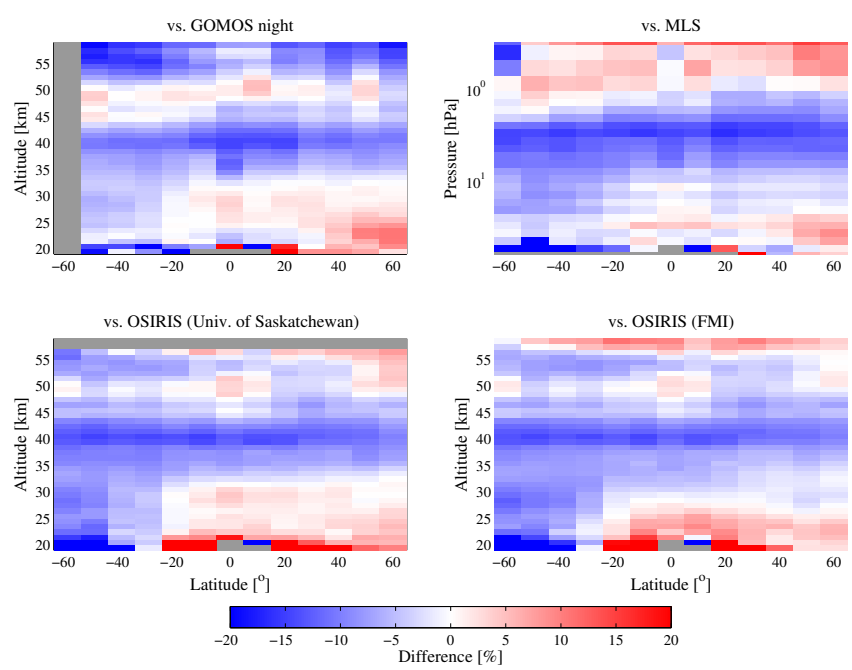

Figure 9. Median relative differences of GBL ozone profiles against GOMOS nighttime occultations (upper left), MLS (upper right), OSIRIS University of Saskatoon version (lower left), and OSIRIS FMI version (lower right).

tropic/sub-tropic regions below $21 \mathrm{~km}$ but the deviations are large too. Remaining differences are below $10 \%$ (and often $<5 \%)$.

\section{Discussion and summary}

We have processed and released a GOMOS bright limb ozone data set. This data set roughly doubles the number of useful GOMOS ozone profiles. In general, the bias in the GBL ozone is less than $10 \%$, and often less than $5 \%$, but there is a clear $10-13 \%$ negative bias at $40 \mathrm{~km}$. The reason for this bias is uncertain but the most likely cause is the stray light contamination in the $300-320 \mathrm{~nm}$ band already noted by Tukiainen et al. (2011). Above the $45 \mathrm{~km}$ tangent height, we use UV wavelengths to retrieve ozone and below $40 \mathrm{~km}$ we use visible wavelengths. The retrieval method is sensitive to the transition from UV to visible and it is easily disturbed by stray light. As explained above, we scale the amount of stray light to get a smooth ozone profile in the $40 \mathrm{~km}$ transition. This ad hoc approach works reasonably well in practice but better ways to switch between the different wavelength domains should be investigated in future.

The diurnal variation explains about $1-3 \%$ of the observed $40 \mathrm{~km}$ bias as the GOMOS day measurements are made during the minimum of the diurnal cycle. At the $50 \mathrm{~km}$ altitude we have up to $50 \%$ positive bias depending on the solar zenith angle. This bias cannot be explained by natural variation; it indicates some problem in the retrieval, most likely related to the stray light and its correction. Until this issue is solved, it is recommended to only use GBL measurements with a solar zenith angle of less than $75^{\circ}$ when using data from the altitudes above $45 \mathrm{~km}$.
Table 4. Login information for accessing the GBL data.

\begin{tabular}{ll}
\hline Server & ftp.fmi.fi \\
Login & gomosGBL \\
Password & kOs20mos! \\
\hline
\end{tabular}

In this work, we showed the accuracy of the GBL data as a function of latitude, altitude, and solar zenith angle (Figs. $7-$ 9 ). These are the most important variables affecting the overall quality of the profiles. Beside these variables, we have also studied the effect of season, scattering angle, azimuth angle, albedo, and time, but they do not seem to correlate substantially with the bias. The quality of the GBL data could be summarized as follows. The accuracy of the GBL data is better than $10 \%$ between 20 and $35 \mathrm{~km}$. There is a negative bias at $35-45 \mathrm{~km}$ that has a consistent shape with all studied observation conditions. Because of the regular shape, this bias is straightforward to correct if the data is used, for example, in time series studies. Above $45 \mathrm{~km}$, the data is valid with the solar zenith angles of less that $75^{\circ}$ when the accuracy is approximately $15 \%$ or better.

The GBL Level 2 files are available from the FMI's FTP server and the login information is shown in Table 4. The file format is HDF5 (one file for each profile) and the total size of the whole data set is about $22 \mathrm{~GB}$.

Acknowledgements. This study was funded by the European Space Agency through the SPIN project (http://esa-spin.org) and by the Academy of Finland through the MIDAT project. The authors wish to thank the three referees for reviewing the manuscript and for suggesting relevant corrections. The authors also appreciate the MLS and OSIRIS teams for sharing their data. Special thanks go to Viktoria Sofieva for valuable suggestions. The (ozone sounding) data used in this publication were obtained as part of the Network for the Detection of Atmospheric Composition Change (NDACC) and are publicly available (see http://www.ndacc.org).

Edited by: C. von Savigny

\section{References}

Adams, C., Strong, K., Batchelor, R. L., Bernath, P. F., Brohede, S., Boone, C., Degenstein, D., Daffer, W. H., Drummond, J. R., Fogal, P. F., Farahani, E., Fayt, C., Fraser, A., Goutail, F., Hendrick, F., Kolonjari, F., Lindenmaier, R., Manney, G., McElroy, C. T., McLinden, C. A., Mendonca, J., Park, J.-H., Pavlovic, B., Pazmino, A., Roth, C., Savastiouk, V., Walker, K. A., Weaver, D., and Zhao, X.: Validation of ACE and OSIRIS ozone and $\mathrm{NO}_{2}$ measurements using ground-based instruments at $80^{\circ} \mathrm{N}$, Atmos. Meas. Tech., 5, 927-953, doi:10.5194/amt-5-927-2012, 2012.

Adams, C., Bourassa, A. E., Bathgate, A. F., McLinden, C. A., Lloyd, N. D., Roth, C. Z., Llewellyn, E. J., Zawodny, J. M., Flittner, D. E., Manney, G. L., Daffer, W. H., and Degenstein, D. A.: Characterization of Odin-OSIRIS ozone profiles with the SAGE 
II dataset, Atmos. Meas. Tech., 6, 1447-1459, doi:10.5194/amt6-1447-2013, 2013.

Bertaux, J. L., Kyrölä, E., Fussen, D., Hauchecorne, A., Dalaudier, F., Sofieva, V., Tamminen, J., Vanhellemont, F., Fanton d'Andon, O., Barrot, G., Mangin, A., Blanot, L., Lebrun, J. C., Pérot, K., Fehr, T., Saavedra, L., Leppelmeier, G. W., and Fraisse, R.: Global ozone monitoring by occultation of stars: an overview of GOMOS measurements on ENVISAT, Atmos. Chem. Phys., 10, 12091-12148, doi:10.5194/acp-10-12091-2010, 2010.

Degenstein, D. A., Bourassa, A. E., Roth, C. Z., and Llewellyn, E. J.: Limb scatter ozone retrieval from 10 to $60 \mathrm{~km}$ using a multiplicative algebraic reconstruction technique, Atmos. Chem. Phys., 9, 6521-6529, doi:10.5194/acp-9-6521-2009, 2009.

ESA: GOMOS Level 2 Product Quality Readme File, available at: https://earth.esa.int/documents/700255/708000/RMF_0117_ GOM_NL\%2P_Disclaimers.pdf (last access: 21 April 2015), 2012.

Froidevaux, L., Jiang, Y. B., Lambert, A., Livesey, N. J., Read, W. G., Waters, J. W., Browell, E. V., Hair, J. W., Avery, M. A., McGee, T. J., Twigg, L. W., Sumnicht, . G. K., Jucks, K. W., Margitan, J. J., Sen, B., Stachnik, R. A., Toon, G. C., Bernath, P. F., Boone, C. D., Walker, K. A., Filipiak, M. J., Harwood, R. S., Fuller, R. A., Manñey, G. L., Schwartz, M. J., Daffer, W. H., Drouin, B. J., Cofield, R. E., Cuddy, D. T., Jarnot, R. F., Knosp, B. W., Perun, V. S., Snyder, W. V., Stek, P. C., Thurstans, R. P., and Wagner, P. A.: Validation of Aura Microwave Limb Sounder stratospheric ozone measurements, J. Geophys. Res.Atmos., 113, D15S20, doi:10.1029/2007JD008771, 2008.

Kyrölä, E., Laine, M., Sofieva, V., Tamminen, J., Päivärinta, S.-M., Tukiainen, S., Zawodny, J., and Thomason, L.: Combined SAGE II-GOMOS ozone profile data set for 1984-2011 and trend analysis of the vertical distribution of ozone, Atmos. Chem. Phys., 13, 10645-10658, doi:10.5194/acp-13-10645-2013, 2013.

Livesey, N. J., Read, W. G., Froidevaux, L., Lambert, A., Manney, G. L., Pumphrey, H. C., Santee, M. L., Schwartz, M. J., Wang, S., Cofield, R. E., Cuddy, D. T., Fuller, R. A., Jarnot, R. F., Jiang, J. H., Knosp, B. W., Stek, P. C., Wagner, P. A., and Wu, D. L.: EOS MLS Version 3.3 Level 2 data quality and description document, JPL D-33509, Jet Propulsion Laboratory, Version 3.3x-1.0, available at: https://mls.jpl.nasa.gov/data/ v3-3_data_quality_document.pdf (last access: 5 August 2015), 18 January 2011.

Llewellyn, E. J., Lloyd, N. D., Degenstein, D. A., Gattinger, R. L., Petelina, S. V., Bourassa, A. E., Wiensz, J. T., Ivanov, E. V., McDade, I. C., Solheim, B. H., McConnell, J. C., Haley, C. S., von Savigny, C., Sioris, C. E., McLinden, C. A., Griffioen, E., Kaminski, J., Evans, W. F., Puckrin, E., Strong, K., Wehrle, V., Hum, R. H., Kendall, D. J., Matsushita, J., Murtagh, D. P., Brohede, S., Stegman, J., Witt, G., Barnes, G., Payne, W. F., Piché, L., Smith, K., Warshaw, G., Deslauniers, D. L., Marchand, P., Richardson, E. H., King, R. A., Wevers, I., McCreath, W., Kyrölä, E., Oikarinen, L., Leppelmeier, G. W., Auvinen, H., Mégie, G., Hauchecorne, A., Lefèvre, F., de La Nöe, J., Ricaud, P., Frisk, U., Sjoberg, F., von Schéele, F., and Nordh, L.: The OSIRIS instrument on the Odin spacecraft, Can. J. Phys., 82, 411-422, doi:10.1139/p04-005, 2004.

McLinden, C. A., Bourassa, A. E., Brohede, S., Cooper, M., Degenstein, D. A., Evans, W. J. F., Gattinger, R. L., Haley, C. S., Llewellyn, E. J., Lloyd, N. D., Loewen, P., Martin, R. V., Mc-
Connell, J. C., McDade, I. C., Murtagh, D., Rieger, L., von Savigny, C., Sheese, P. E., Sioris, C. E., Solheim, B., and Strong, K.: OSIRIS: A Decade of Scattered Light, B. Am. Meteorol. Soc., 93, 1845-1863, doi:10.1175/BAMS-D-11-00135.1, 2012.

Meijer, Y. J., Swart, D. P. J., Allaart, M., Andersen, S. B., Bodeker, G., Boyd, I., Braathen, G., Calisesi, Y., Claude, H., Dorokhov, V., von der Gathen, P., Gil, M., Godin-Beekmann, S., Goutail, F., Hansen, G., Karpetchko, A., Keckhut, P., Kelder, H. M., Koelemeijer, R., Kois, B., Koopman, R. M., Kopp, G., Lambert, J.C., Leblanc, T., McDermid, I. S., Pal, S., Schets, H., Stubi, R., Suortti, T., Visconti, G., and Yela, M.: Pole-to-pole validation of Envisat GOMOS ozone profiles using data from ground-based and balloon sonde measurements, J. Geophys. Res.-Atmos., 109, D23305, doi:10.1029/2004JD004834, 2004.

Sakazaki, T., Fujiwara, M., Mitsuda, C., Imai, K., Manago, N., Naito, Y., Nakamura, T., Akiyoshi, H., Kinnison, D., Sano, T., Suzuki, M., and Shiotani, M.: Diurnal ozone variations in the stratosphere revealed in observations from the Superconducting Submillimeter-Wave Limb-Emission Sounder (SMILES) on board the International Space Station (ISS), J. Geophys. Res.Atmos., 118, 2991-3006, doi:10.1002/jgrd.50220, 2013.

Taha, G., Jaross, G., Fussen, D., Vanhellemont, F., Kyrölä, E., and McPeters, R. D.: Ozone profile retrieval from GOMOS limb scattering measurements, J. Geophys. Res.-Atmos., 113, D23307, doi:10.1029/2007JD009409, 2008.

Tamminen, J., Kyrölä, E., Sofieva, V. F., Laine, M., Bertaux, J.-L., Hauchecorne, A., Dalaudier, F., Fussen, D., Vanhellemont, F., Fanton-d'Andon, O., Barrot, G., Mangin, A., Guirlet, M., Blanot, L., Fehr, T., Saavedra de Miguel, L., and Fraisse, R.: GOMOS data characterisation and error estimation, Atmos. Chem. Phys., 10, 9505-9519, doi:10.5194/acp-10-9505-2010, 2010.

Tukiainen, S., Hassinen, S., Seppälä, A., Auvinen, H., Kyrölä, E., Tamminen, J., Haley, C. S., Lloyd, N., and Verronen, P. T.: Description and validation of a limb scatter retrieval method for Odin/OSIRIS, J. Geophys.l Res.-Atmos., 113, D04308, doi:10.1029/2007JD008591, 2008.

Tukiainen, S., Kyrölä, E., Verronen, P. T., Fussen, D., Blanot, L., Barrot, G., Hauchecorne, A., and Lloyd, N.: Retrieval of ozone profiles from GOMOS limb scattered measurements, Atmos. Meas. Tech., 4, 659-667, doi:10.5194/amt-4-659-2011, 2011.

van Gijsel, J. A. E., Swart, D. P. J., Baray, J.-L., Bencherif, H., Claude, H., Fehr, T., Godin-Beekmann, S., Hansen, G. H., Keckhut, P., Leblanc, T., McDermid, I. S., Meijer, Y. J., Nakane, H., Quel, E. J., Stebel, K., Steinbrecht, W., Strawbridge, K. B., Tatarov, B. I., and Wolfram, E. A.: GOMOS ozone profile validation using ground-based and balloon sonde measurements, Atmos. Chem. Phys., 10, 10473-10488, doi:10.5194/acp10-10473-2010, 2010.

Verronen, P. T., Kyrölä, E., Tamminen, J., Sofieva, V. F., Clarmann, T., Stiller, G. P., Kaufmann, M., Lopez-Puertas, M., Funke, B., and Bermejo-Pantaleon, D.: A Comparison of Daytime and Night-Time Ozone Profiles from GOMOS and MIPAS, in: Proceedings of the Envisat Symposium 2007, Montreux, Switzerland, ESA SP-636, July 2007, 462479, available at: https://earth.esa.int/workshops/envisatsymposium/ proceedings/sessions/2A3/462479bv.pdf (last access: 5 August 2015), 2007.

Waters, J. W., Froidevaux, L., Harwood, R. S., Jarnot, R. F., Pickett, H. M., Read, W. G., Siegel, P. H., Cofield, R. E., Filipiak, M. J., 
Flower, D. A., Holden, J. R., Lau, G. K., Livesey, N. J., Manney, G. L., Pumphrey, H. C., Santee, M. L., Wu, D. L., Cuddy, D. T., Lay, R. R., Loo, M. S., Perun, V. S., Schwartz, M. J., Stek, P. C., Thurstans, R. P., Boyles, M. A., Chandra, K. M., Chavez, M. C., Chen, G.-S., Chudasama, B. V., Dodge, R., Fuller, R. A., Girard, M. A., Jiang, J. H., Jiang, Y., Knosp, B. W., Labelle, R. C., Lam, J. C., Lee, A. K., Miller, D., Oswald, J. E., Patel, N. C., Pukala, D. M., Quintero, O., Scaff, D. M., Vansnyder, W., Tope, M. C., Wagner, P. A., and Walch, M. J.: The Earth Observing System Microwave Limb Sounder (EOS MLS) on the Aura satellite, IEEE Trans. Geosci. Remote Sens., 44, 10751092, doi:10.1109/TGRS.2006.873771, 2006. 